\title{
STRUCTURAL AND SPATIAL CHANGES IN AGRICULTURE
}

https://doi.org/10.4215/rm2019.e18022

\author{
Fernando Mesquita $a^{*}$ - André Tosi Furtado ${ }^{b}$
}

(a) Dr. in Geography. Professor Campinas State Universit, Campinas (SP), Brazil.

ORCID: https://orcid.org/0000-0002-8192-2263. LATTES: http://lattes.cnpq.br/0116848016427400.

(b) Dr. in Economy. Professor Campinas State Universit, Campinas (SP), Brazil.

ORCID: https://orcid.org/0000-0002-6183-192X. LATTES: http://lattes.cnpq.br/8444233927942764.

\author{
Article history: \\ Received 30 June, 2019 \\ Accepted 5 October, 2019 \\ Publisher 15 October, 2019
}

(*) CORRESPONDING AUTHOR

Address: UNICAMP - Instituto de Geociências. R. Carlos Gomes, 250 - Cidade Universitária, Campinas - SP, 13083-855. Tel. (+55 19) 35212581

E-mail: fernandomesquita@gmail.com

\begin{abstract}
From a region where until the end of XIX century the cattle was the only profitable production, the South of the State of Goiás became one of the cores of Brazilian agribusiness. Besides the cattle, the region also stands out in the production of soybean, corn, sugarcane, and poultry. This change involved different process of regional and urban organization. Using the South of Goiás case, this paper aims to comprehend how structural and spatial changes were combined in the transformation of a late region in a dynamic agricultural region. To study this process, the structural changes of this region were divided into four phases. The spatial changes were thought according to four possibilities based on fragmentation and integration forces. The idea is to combine both structural and spatial changes to define the historical trajectory of urban and regional growth in the South of Goiás.
\end{abstract}

Keywords: Agribusiness; Structural Changes; Spatial Changes; South of Goiás.

\section{Resumo / Résumé}

\section{MUDANÇAS ESTRUTURAIS E ESPACIAIS NA AGRICULTURA}

De uma região onde até finais do século XIX apenas a pecuária despontava como atividade de maior rentabilidade, a porção sul do Estado de Goiás se transformou em um dos principais centros do agronegócio nacional. Além da pecuária, destaca-se a produção de soja, milho, cana-de-acúcar e a avicultura. Essa transformação envolveu diferentes processos de organização urbana e regional. Por meio do caso do sul de Goiás, o objetivo é compreender como que mudanças estruturais e espaciais se combinaram na transformação de uma região atrasada em uma região agrícola dinâmica. Para estudar esse processo, as mudanças estruturais da região foram divididas em quatro fases. As mudanças espaciais foram divididas em quatro possibilidades baseadas em forças de fragmentação e integração. Busca-se combinar as mudanças estruturais e espaciais de forma a traçar a trajetória histórica de crescimento agrícola, urbano e regional do sul de Goiás.

Palavras-chave: Agronegócio; Mudanças Estruturais; Mudanças Espaciais; sul de Goiás

\section{CHANGEMENTS STRUCTURELS ET SPATIAUX DANS L’AGRICULTURE}

Partant d'une region dans laquelle jusqu'à la fin du XIX siècle seul l'élevage etait rentable, le sud de l'etat de Goiás est devenu un des principaux centres de l'agrobusiness brésilien. En plus du bétail, la región se démarque par sa production de soja, de maíz, canne à sucre, et l'elevage de cochons et de poulets. Ce changement a impliqué dans d'importants processus de transformation urbains et regionaux. À travers l'étude du Sud de Goiás, l'objectif de cet article est d'analyser comment les changements structurels et spatiaux sont liés au processus de transformation d'une region arriérée dans l'une des plus dynamiques de l'agriculture moderne. Pour celà, nous avons fait une périodisation de cette region en quatre phases. Les changements spatiaux ont été separés dans quatre possibilités qui s'appuyent sur l'intensité à travers laquelle le système productif induit les forces d'intégration ou de fragmentation. On cherche à joindre les changements structurels et spatiaux de manière à décrire les changements dans la configuration agricole, urbaine et regionale du sud de l'état de Goiás au cours de son histoire.

Mots-clés: Industrie Agroalimentaire; Changements Structurels; Changements Spatiaux; Sud de Goiás 


\section{INTRODUCTION}

Brazilian agriculture has moved on from being a backward activity, which it had been until the mid-twentieth century (FURTADO, 1972), to become an alternative for economic and regional development (NAVARRO; BUAINAIN, 2018). This change has resulted from public policies (CAMPOLINA, 2006); research conducted mainly by the Brazilian Agricultural Research Corporation (Embrapa) (BONACELLI; FUCK; CASTRO, 2015); adopting the technological standards of the Green Revolution (FREDERICO, 2013); as well as creating regional arrangements adapted for the expansion of large-scale agricultural and agroindustrial production. This article seeks to contribute to the understanding of this last phenomenon.

For this, a study was conducted on the transformation, which has taken place in the southern portion of the state of Goiás. In this region, until the beginning of the twentieth century, the greatest profitability came only from livestock farming (ESTEVAM, 1997). Waibel (1947), in a report drawn up in the 1940s, highlighted the low degree of agricultural development in the state of Goiás, which consisted of clearing forests and occupying new lands. By the end of the twentieth century this situation had become completely different. In addition to livestock, which remains strong within the region, South Goiás has diversified meat production, incorporating the chicken and pork supply chain. Agricultural production has also grown, particularly soybeans, maize and sugarcane. The region has begun to attract large investments of national and multinational capital.

On the one hand, the study approaches the work of Page and Walker (1991) and Page (1996), who demonstrated that the success of agricultural regions is not associated with natural comparative advantages, but with socioeconomic transformations. These regions grow "by producing commodities in demand, improving production methods, multiplying their division of labor, reinvesting capital in further expansion, and remaining competitively viable" (PAGE; WALKER, 1991, p. 282). On the other hand, it is also based on the discussion related to regions of productive agribusiness (RPAs) (ELIAS, 2011) as a way of combining agricultural and agro-industrial growth with changes in the urban and regional configuration.

Using the case of South Goiás, the aim of this paper is to analyze how changes in the productive structure and in the urban and regional configuration have combined to transform less dynamic agricultural regions into regions that are able to guarantee the competitiveness of agricultural and agroindustrial production. This idea therefore, seeks to strengthen the argument that the backwardness of agriculture was not only represented in technical and productive terms, but also spatial.

The methodology is based on a combination of quantitative and qualitative analyzes. To define the different regional arrangements, five categories of analysis were selected: the destination market for production; the links between agriculture and industry; urban growth; the alignment of the transportation system; and the scientific and technological infrastructure. The first three were analyzed using secondary data. The fourth was analyzed by mapping both the highways and railways. For the fifth category, a qualitative study was conducted to identify the type of technique involved in the production system and the growth of scientific and technological infrastructure across the region. For the study, South Goiás was considered as the South Goiás mesoregion, defined by the Brazilian Institute of Geography and Statistics (IBGE), by the grouping of 82 municipalities.

The article is divided into four more sections, apart from this introduction. The second section presents a periodization of the leading activities of agriculture in South Goiás, proposing a division into four phases. The third section presents the proposed method for combining changes in the productive structure and regional arrangements, as well as the analytical categories used to differentiate the urban and regional configurations within a historical process. The fourth section is the study of the economic formation of South Goiás using the periodization and the proposed method. The fifth section presents the conclusions, seeking to synthesize the main arguments of the article.

\section{THE LEADING AGRICULTURAL ACTIVITIES IN SOUTH GOIÁS}

During the colonial period, gold was the first economic activity to grow in Goiás. The main 
region of gold extraction was in central Goiás, where the municipal territories (termed Julgados) were formed of Vila Boa, today Goiás (a municipality), and Meia Ponte, today Pirenópolis. South Goiás had little participation in this process, and so it was decided to define the first historical moment as that which began with the end of the gold cycle.

The decline in gold production brought about an economic recession that led Goiás towards a subsistence regime (PALACIN, 1994). The only activity that was able to overcome these barriers and trade the surplus was livestock. This is due that cattle production needed fewer capital investments in order to operate (ESTEVAM, 1997), and was able to overcome the limits regarding rainfall seasonality in the Cerrado regions.

This productive system, which characterizes the first phase of the proposed periodization, lasted for most of the nineteenth century. Signs of change appeared only at the end of this century due to the solid links that existed between South Goiás and the economy of São Paulo. At that time, the economic dynamism of São Paulo was strong because of the expansion of the coffee complex (CANO, 2007a), increasing the demand for food in other regions. The links with São Paulo favored livestock production, as well as increasing the profitability of agricultural activities by stimulating the commercialization of rice, which had hitherto been linked to small production and to subsistence.

Rice production became economically relevant in South Goiás from the 1930s and 1940s, when the link with São Paulo intensified under the command of industrial capital (CANO, 2007b). Initially, rice planting grew in the central parts of Goiás, around the present location of Ceres, as a result of the "March to the West" during the era of President Vargas (CAMPOLINA, 2006). The greatest sprawl towards South Goiás occurred during the 1940s, as Waibel (1947) reports, induced by the rising prices both during and after World War II and by the fact that rice was suitable for recently deforested areas. The growth of rice caused South Goiás to embark upon a second phase, thereby sharing the command function of regional production with cattle.

Two highly relevant events for the regional economy occurred in Goiás in the 1940s and 1950s. The first was the inauguration of Goiânia, the new state capital, in 1942. The second was moving the federal capital from Rio de Janeiro to Central Brazil, which was completed in 1960. The new federal capital brought with it a number of other projects, including the creation of an agricultural research infrastructure (CAMPOLINA, 2006). The creation of the Brazilian Agricultural Research Corporation (known as Embrapa) dates from 1973, and the installation of Embrapa Cerrados in Brasilia from 1975. This was a milestone for scientific agriculture in Central Brazil. Embrapa Cerrados began to generate, adapt and disseminate fresh knowledge appropriate to the region. These research studies, aligned to the work on genetic improvement of Embrapa Soja, in Londrina, created the basis for the advancement of soybean cultivation in South Goiás. Thus, a crop hitherto external to the region became the main agricultural activity, thus defining entry into the third phase. Since it was common for soybean to advance into rice areas, in this case, the change was in the continuity of livestock with rice being replaced by soybean.

If the third moment is marked by the expansion of soybean, the fourth, after the 2000 s, was defined by a greater diversification of livestock and crop production. This process occurred in two manners: the advance of sugarcane and the growth of the corn and meat chains.

An initial phase of sugarcane expansion in South Goiás came between 1979 and 1991, induced by the effects of the first and second National Alcohol Program (Proálcool). However, the growth of sugarcane activity as a major product in the regional economy appeared from 2000, when the sugar-energy sector grew due to the increased demand for ethanol (CASTILLO, 2015). Given the difficulty of expanding production in traditional regions of São Paulo (FIGUEIRA; BELIK; VICENTE, 2014), companies in the sector sought new areas in the expansion zones of the Triangulo Mineiro (the Minas Gerais Triangle), northern Paraná, Southwest Mato Grosso do Sul and South Goiás. The second movement of diversification occurred with the diffusion of the crop rotation system with soybean and maize. Along with the expansion of maize, a force of attraction was created for meat processing companies, especially BRF, which operated in the area of poultry and pork.

This therefore, stands as justification for dividing the productive structure of South Goiás into four phases. This periodization is expressed in Table 1. 


\begin{tabular}{c|c|c} 
Phase & Period & Main activities \\
\hline First & Beginning of the nineteenth century until the mid-1920s & Livestock \\
\hline Second & Mid-1940s until the mid-1970s & Livestock/Rice \\
\hline Third & Mid-1970s until the beginning of the 2000s & Livestock/Soybean \\
\hline Fourth & The 2000s until the present day & $\begin{array}{c}\text { Livestock/grains (soybean-maize) } \\
\text { and meat/sugarcane }\end{array}$
\end{tabular}

Table 1 - Structural changes in South Goiás

As Page (1996) indicated, each agricultural product produces a particular relationship with the region. Each crop or livestock has its own reproduction and growth rate, requiring specific management that varies according to size, weight, shape, durability and perishability (PAGE, 1996). Each product has a particular type of interaction with industry, requiring specific processing forms, machinery and chemical inputs. Each product demands a particular type of service (ELIAS, 2011), requires its own logistics system and has particular relationships with the labor market. Thus, each change in agricultural production tends to be linked with a change in the regional arrangement.

\section{STRUCTURAL AND SPATIAL CHANGES: THE CONFIGURATION OF REGIONAL ARRANGEMENTS}

The first idea to combine changes in productive structure with changes in regional arrangements was to consider, similar to Mendez (1997), that the interrelationships between economy and space are dialectically constituted. Thus, productive changes both influence and are influenced by changes in the region.

The second point is to consider regional changes in association with forces of integration and disintegration. These concepts are based, respectively, on what Haesbaert (2001) defines as traditional territorial logic, guided by a cohesion pattern, and a reticular logic, based on a territory-network system. With emphasis on the economic dimension, these logics are guided by the dynamics of the productive system, in this case, by the type of interaction that companies establish with suppliers; by the relations with the consumer and labor markets; and by the form of acquiring technologies and knowledge. These relationships may create systems, which are either more regionally cohesive or more dispersed (STORPER, 1997).

Based on these considerations and seeking an operational definition for the research objective, it was understood that integration forces are associated with productive activities that create interdependent ties with the region. Disintegration forces occur as increased production broadens the links with logics external to their domains. In specialized regions, this linkage of forces depends essentially on the organization of the main activity. In diversified regions, multiple logics occur simultaneously.

Similar to the work by Storper (1997), a distinction is made between four regional arrangements designed from the intensities with which forces of integration and disintegration manifest themselves. These possibilities are outlined in Figure 1. 


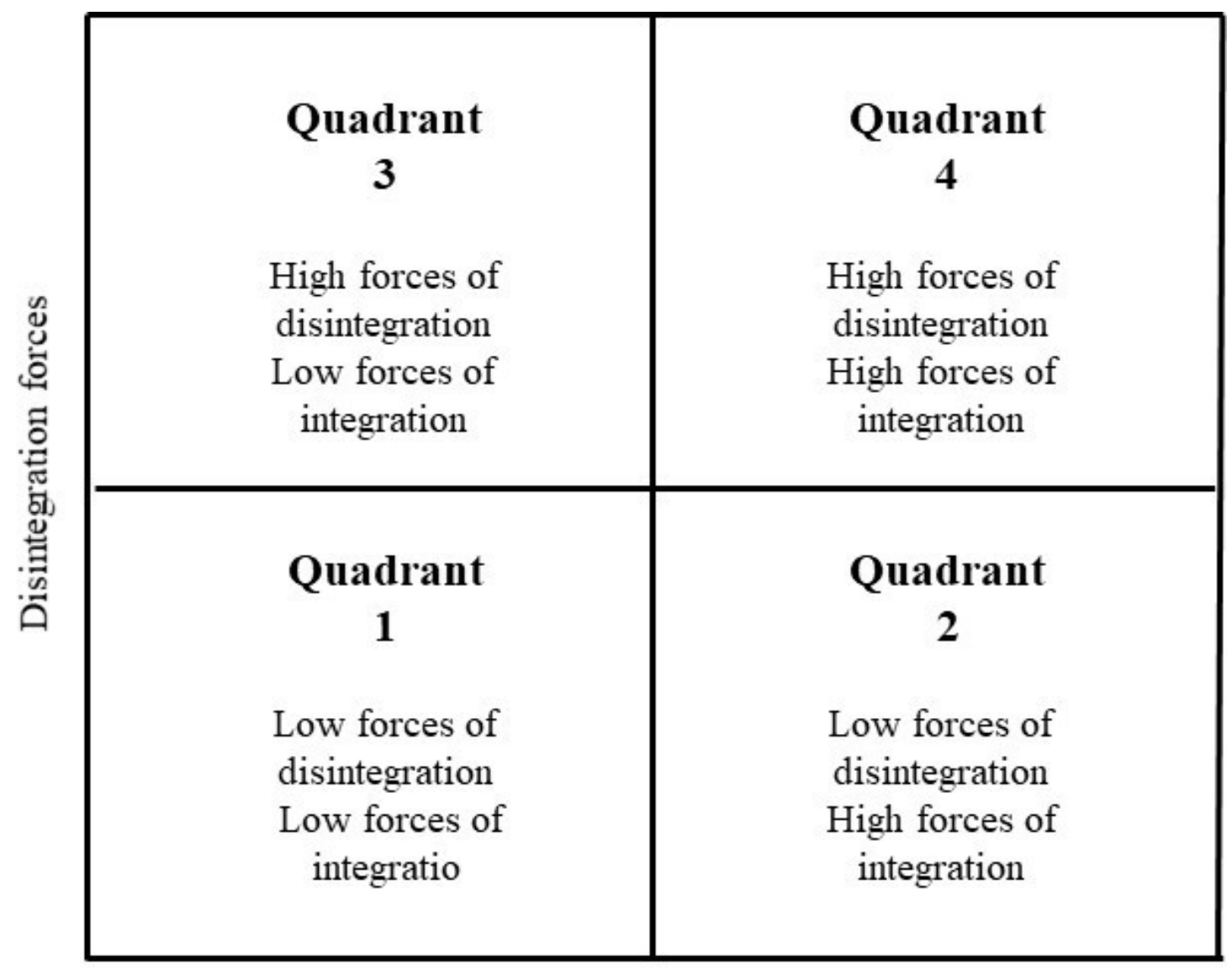

Integration forces

Figure 1. Regional arrangements related to the forces of integration and disintegration. Source: Produced by the authors, 2018. Based on Storper (1997)

The proposal is to conduct a historical reading of Figure 1, including the transitional possibilities between Quadrants 1, 2, 3 and 4. For example, a region may begin its trajectory with the conditions described in Quadrant 1, but as new products grow, arrangements may be incorporated that lead it on to other Quadrants (2, 3 or 4$)$.

To distinguish this trajectory, a procedure was adopted that created five categories of analysis, which are associated with the economic arrangement of the region, followed by a discussion on how each category fits into Quadrants 1,2, 3 or 4. The categories are: (i) the destination market for production; (ii) the capability to generate industrial linkages and their locations; (iii) the size of urban centers; (iv) the alignment of the transportation system; and (v) the scientific and technological infrastructure.

The first category refers to the destination market for the production of the region's main economic activity. In the sense provided by North (1955), it was considered that the leading activities supply markets beyond the boundaries of the region. The idea was to distinguish products that are limited to the domestic market from those destined for export. Quadrants 1 and 2 indicate activities associated with the domestic market, while Quadrants 3 and 4 indicate products aimed at the international market. To define the extent of the market, in phases 1 and 2 of the periodization proposed in the previous item, we referred to the specialized literature on the economic history of Goiás, and in phases 3 and 4 we used data from the Ministry of Development, Industry and Foreign Trade (MDIC) between 1997 and 2017. (BRAZIL, 2019a).

The second category refers to the capacity to generate industrial linkages and their locations. In line with the concept of the Agroindustrial Complex (CAI) (MULLER, 1982), it is understood that there are two types of linkages between agriculture and industry: upstream, in terms of the interaction with 
machinery, tools, pesticides and chemical fertilizers; and downstream, in terms of processing raw materials. This category provides the possibility to ascertain the productive sophistication of the region, since the upstream sector allows the development of an industrial base of production goods and the downstream sector brings added value to primary production. Agricultural activity may have a low ability to generate linkages (Quadrants 1 and 2); and may also create them in other regions (Quadrant 3), or may generate linkages that are essentially internal to the region, thereby generating additional externalities that strengthen the place due to the proximity of the industry to agricultural producers (Quadrant 4).

In this second category, data analysis was not only performed for South Goiás, but for the State of Goiás as a whole. In this study, in phase 1, a literature review was used to identify which activities were growing alongside livestock. In phase 2, to define the downstream sector, data from the 1970 Industrial Census were used to measure the value of industrial transformation (VIT) in the food and beverage sectors (IBGE, 1974). To define the upstream sector, we included the mechanical industry (which includes the agricultural equipment sector) and the chemical industry (which incorporates the pesticide and fertilizer sector). For phases 3 and 4, special tabulations were used from the Annual Industrial Survey (PIA) - Company (IBGE, 2019b). For the downstream activities, we analyzed the two-digit sectors from the National Classification of Economic Activities (CNAE 2.0), the manufacturing of food products and the manufacturing of beverages, and the three-digit sector, biofuel manufacturing. For upstream activities, the three-digit sectors were analyzed: the manufacture of pesticides and household pest controls and the manufacture of tractors and machinery and equipment for agriculture and livestock (upstream sectors).

The third category refers to the size of urban centers. Cities are central to agricultural regions. The growth of agriculture depends on a greater social division of labor between countryside-city, as well as between cities (PAGE; WALKER, 1991). As Page and Walker (1991) stated, cities offer greater accessibility to the farms; provide the intermediation with commercial capital; and increase the availability of labor within the region. Considering the context of globalization, Elias (2011, p. 159) indicated that "intensive agricultural and agroindustrial production requires that urban spaces near the rationalized agricultural space adapt to meet their main demands".

For the analysis of urban centers, it is considered that cities with a population of less than 10 thousand present a lower potential to generate the effects of boosting agriculture growth, while cities with a population of more than 40 thousand present a higher potential. Thus, we analyzed the number of cities within these demographic levels. The urbanization rate of the region was also computed. This was only possible for phases 2,3 and 4, when we obtained the regional demographic census data (IBGE 2018c) and the population count (2017) (IBGE 2018d). For phase 1, the analysis was based on population information available in historical studies on Goiás. It is understood that Quadrants 1, 2 and 3 registered a lower number of relevant urban centers. Quadrant 4 has a higher number of urban centers with a more representative size for the region.

The fourth category is the alignment of the transport system. The means of transport is able to transfer region's agricultural production to external centers, as well as inducing greater links within the interregional urban network. Quadrants 1 and 2, given the lack of regional urban centers and the low amplitude of the market, tend to present poorer transport systems. In Quadrant 3, transport acts as a strategic material base for links to the foreign market, interlinking the region to export ports. In Quadrant 4 the transport system follows the urban network, promoting greater intra-regional links.

To analyze the means of transport, the road and rail systems in South Goiás were mapped. Shapefiles were produced from historical maps provided by the Ministry of Transport, Ports and Civil Aviation for the phase 2 study and ready-made shapefiles were used from the Goiás State Geoinformation System (SIEG) for phase 4. In order to complement this work, the regional transport system map was superimposed onto the classifications of the municipalities with the largest population and the location of the downstream industry (which, as will be demonstrated, is the most representative in the region). Thus, we sought maps that illustrated a combination of urban networks and industrial locations.

The fifth category refers to scientific and technological infrastructure. This category discusses the region's ability to produce or absorb scientific knowledge. In this case, the approach is basically 
qualitative. The following procedure was adopted: first, consider the type of technique - or, the intrinsic characteristics of the agricultural sector (CASTILLO, 2015) - involved in the leading activities. This may be an itinerant agriculture (FURTADO, 1972) or a scientific agriculture (SANTOS, 2010). The first defines Quadrant 1, while the second may characterize Quadrants 3 or 4 . The difference is in the characteristics of the productive activity. When it comes to an extensive activity with a higher degree of technical maturity, there is a tendency for a growth with a low dependence on the scientific infrastructure of the region, thereby leading to the logic of Quadrant 3. With an intensive activity, in which the technique is undergoing a process of development, growth tends to demand greater investments in research. In this case, the link with the local scientific and technological infrastructures becomes central. The role of the region's university system becomes more relevant. Universities are responsible for the continuous flow of qualified professionals and for encouraging research. The location in the region enhances the link with local economic interests, improving the techniques involved in production (DINIZ; VIERIA, 2015). It is understood that under these conditions a scientific agriculture is created, which is more closely linked to the logic of Quadrant 4.

Table 2 summarizes the core information discussed in the five categories of analysis and the manner in which they are linked to the quadrants.

\begin{tabular}{c|c|c|c|c} 
Categories of analysis & Quadrant 1 & Quadrant 2 & Quadrant 3 & Quadrant 4 \\
\hline $\begin{array}{c}\text { Destination market for } \\
\text { production }\end{array}$ & National & National & International & International \\
\hline $\begin{array}{c}\text { Capacity to generate and } \\
\text { locate industrial linkages }\end{array}$ & $\begin{array}{c}\text { Low capacity to } \\
\text { generate linkages }\end{array}$ & $\begin{array}{c}\text { Low capacity to } \\
\text { generate linkages }\end{array}$ & $\begin{array}{c}\text { High capacity to generate } \\
\text { linkages, but are } \\
\text { essentially external }\end{array}$ & $\begin{array}{c}\text { High capacity to generate } \\
\text { linkages and are essentially } \\
\text { internal }\end{array}$ \\
\hline Size of urban centers & Few urban linkages & Few urban linkages & $\begin{array}{c}\text { Few urban centers of any } \\
\text { great relevance }\end{array}$ & $\begin{array}{c}\text { High number of relevant } \\
\text { urban centers }\end{array}$ \\
\hline Transport System & Low integration & Local integration & Integrated with ports & Integrated locally \\
\hline $\begin{array}{c}\text { Scientific and technologic } \\
\text { infrastructures }\end{array}$ & $\begin{array}{c}\text { Itinerant technique } \\
\text { and absence of } \\
\text { scientific content }\end{array}$ & $\begin{array}{c}\text { Linked to traditional, } \\
\text { cultural factors of the } \\
\text { place }\end{array}$ & $\begin{array}{c}\text { High use of science and } \\
\text { technology, but few ties } \\
\text { to local research }\end{array}$ & $\begin{array}{c}\text { High use of Science and } \\
\text { technology, and strongly } \\
\text { tied to local research }\end{array}$
\end{tabular}

Table 2 - Categories of analysis and the relationship with Quadrants 1, 2, 3 and 4. Source: Produced by the authors, 2018

In short, disintegration forces predominate when: the market is international; the generated linkages are external to the region; few urban centers grow within the region; transport is aligned towards a global link; and the production technique does not dispense with an infrastructure of scientific knowledge. Integration forces occur when: productive linkages are present in the region; more relevant and interconnected urban centers grow; and new investments in universities increase the region's autonomy in the production technique. It is in this set of forces that the link between structural and spatial changes is defined.

\section{THE TRAJECTORY OF SOUTH GOIÁS THROUGH QUADRANTS 1, 3 AND 4}

This item discusses how each of the four phases that marked the history of agriculture in South Goiás created very particular regional arrangements. It is understood that the first two phases were linked to Quadrant 1. A change occurred with phase 3, which took the regional system onto Quadrant 3. This condition changed with phase 4, which directed the region towards Quadrant 4. Figure 2 represents this trajectory: 


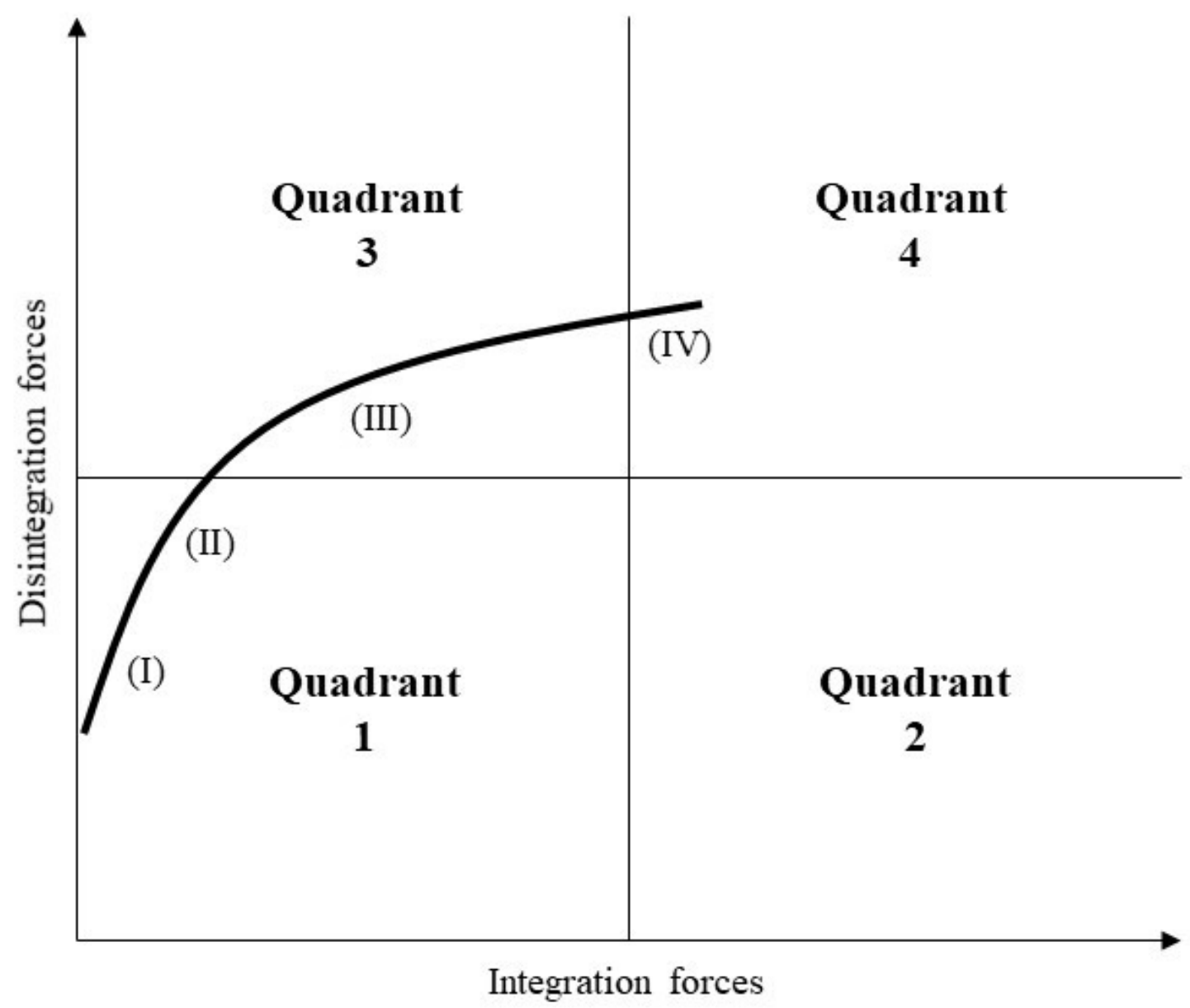

Figure 2 - The economic trajectory in the southern portion of Goiás. Source: Produced by the authors, 2018

Key: (I) livestock; (II) livestock/rice; (III) livestock/soybean; and (IV) livestock/cereals-meat/sugarcane

\section{Phase 1: The Beginning Through Quadrant 1}

The destination market for livestock was domestic. While at first, during the first half of the nineteenth century, the main market of Goiás was Rio de Janeiro, towards the end of the century, São Paulo became its main market (MAMIGONIAN, 2004).

It is important to consider that South Goiás was responsible for only part of a meat production circuit, related to raising livestock. The effects of linkage were, in this context, limited. Historical literature mentions small industries in Catalão for the production of leather and dried meat (charque) (CHAUL, 2011). The regional productive linkage created by livestock farming was with local agriculture due to the demand for maize for animal feed.

During the nineteenth century, new cities emerged in South Goiás, such as Rio Verde, Mineiros, Caiapônia, Jataí, Quirinópolis, Cachoeira Alta, Itarumã, Itumbiara, Caldas Novas and Campo Alegre de Goiás. This moment marked a reduction in the indigenous population and an increase in the population flow from the states of Minas Gerais and São Paulo (ESTEVAM, 1997; PALACIN, 1994).

There was no link with an urban network, but "islands" of residents across the region. During most of the nineteenth century, transport was deficient both in the sense of an intra-regional link as well as integrating South Goiás to other regions of the country. This situation only changed at the beginning of the twentieth century with the expansion of the São Paulo railroad into Central Brazil. The railroad that linked South Goiás with São Paulo was the Mogiana. Entry into Goiás began in 1913, when the 
Araguari branch in the Mina Triangle extended to Goiandira and Ipameri. In 1914, Pires do Rio was included on this route. Ten years later, the railroad arrived in Vianópolis; in 1930, in Leopoldo de Bulhões and, in 1935, in Anápolis.

The lack of universities was not only a particularity of South Goiás, but of Brazil as a whole. The first universities created in the country date from the 1920s and 1930s, and were installed in São Paulo, Rio de Janeiro and Minas Gerais. However, this does not signify that there were no technical improvements in raising livestock. Cattle, initially brought from Rio Grande do Sul, were unaccustomed to the climate and feed in Central Brazil and, therefore, lost weight (ESPÍNDOLA, 2005). In 1875, with the initiative of cattle ranchers from the Minas Triangle and South Goiás, Zebu cattle from India started to become the best herd for commercial livestock in the tropics (VALVERDE, 1985).

The idea is that cattle raising in South Goiás, in phase 1, represents a regional arrangement based on Quadrant 1. This is a characteristic system of poorly dynamic agricultural regions.

\section{Phase 2: Remaining In Quadrant 1}

An increase in rice plantations was responsible for the first diversification in South Goiás, which combined livestock and crop production. São Paulo remained the main market, although it is noteworthy that given the advancement of urbanization, particularly greater São Paulo (CANO, 2007b), this was an expanding market.

Agriculture across the region increased its demand for industrial goods, such as mechanical-powered plows and harvesters. However, local productive linkages remained weak. In the upstream industry, while, on the one hand, São Paulo stimulated food production, on the other, it blocked the capital goods industry (CANO, 2007b). In 1959, the mechanical industry in Goiás represented $0.4 \%$ of the VIT in the State of Goiás and the chemical industry registered $0.2 \%$. In 1970 , both accounted for $1.5 \%$ of the VIT in Goiás (IBGE, 1974). The alternative was downstream industrialization. In 1970, the food sector accounted for $57.4 \%$ of the VIT in the State of Goiás and the beverage sector for $2.5 \%$. In 1960, Goiás accounted for $1.4 \%$ of the VIT of the food sector across the whole country. By 1970, this percentage had increased to 3.0\% (IBGE, 1974).

In 1970, the population of the South Goiás mesoregion was 713 thousand. Of this total, 40.1\% were urban and 59.9\% rural. In South Goiás, there were 36 municipalities with a population of under 10 thousand; 9 municipalities with between 10 and 20 thousand; 10 municipalities with between 20 and 40 thousand; and only three with a population of more than 40 thousand (Itumbiara, Rio Verde and Jataí).

There was an improvement in the transport system, especially with the construction of the road network. Until 1950, regional integration was made along dirt tracks that connected the interior cities with the railroad. It was only with the inauguration of Brasilia that there was an increase in projects to improve the highway modal. In 1960, the paving of the Itumbiara-Goiânia axis was completed, which created a direct link with São Paulo through São José do Rio Preto. In 1970, two roads were connected to this axis: the Rio Verde-Itumbiara and the Morrinhos-Caldas Novas.

Figure 3 illustrates South Goiás in 1970, when there were still no processing industries in the region, few relevant municipalities in terms of population and the transport system connected only a few points across the region. 

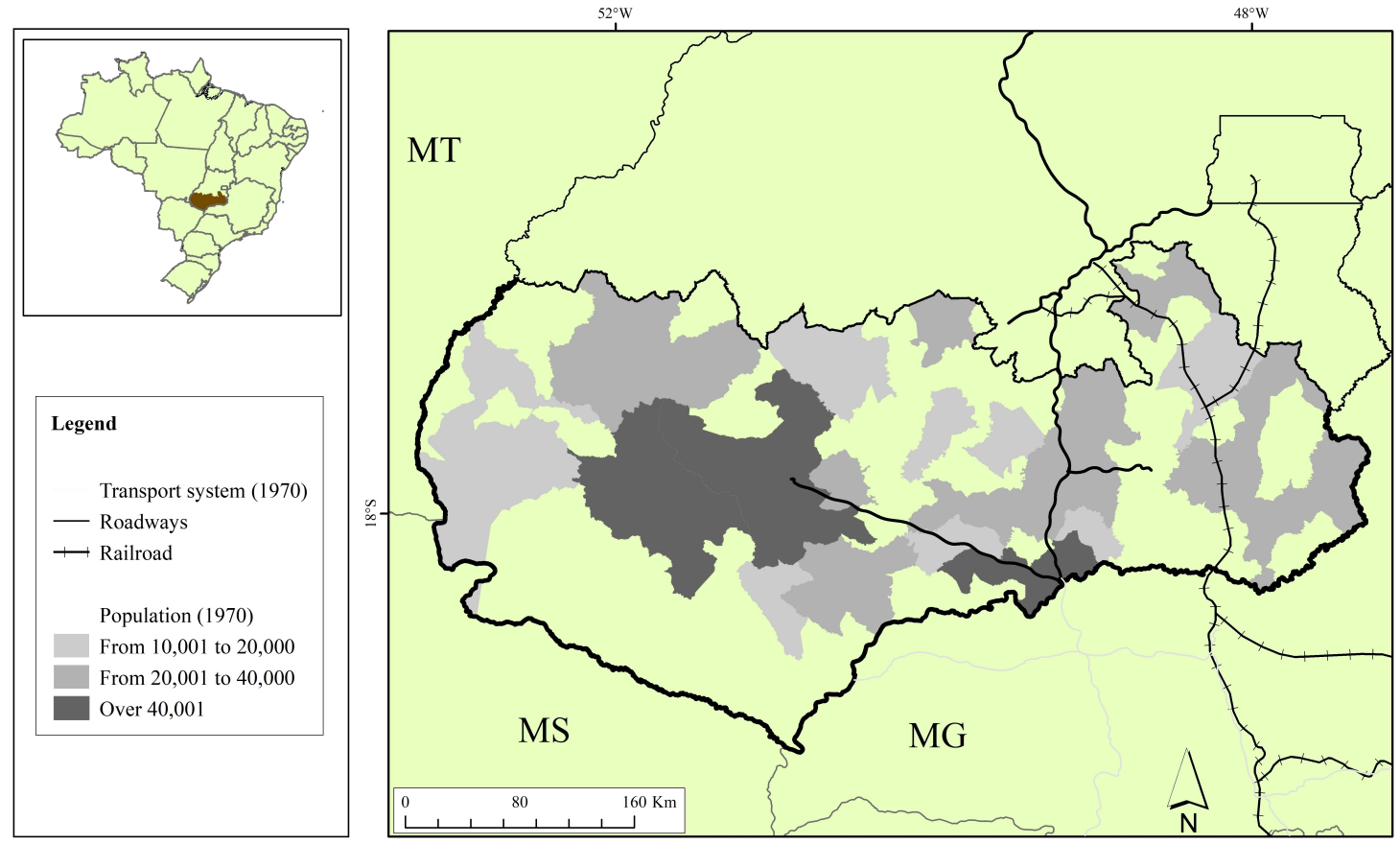

Figure 3 - The South Goiás mesoregion in phase 2: population and transport systems in 1970. Source: Produced by the authors, 2018. Demographic Census Database (2018c) and MTPA (2018)

The university system in the Midwest began to emerge with the installation of the Universidade Federal de Goiás (UFG) in 1960 in Goiânia; and the Universidade de Brasilia (UNB), in 1962, which would also be an important research center for the Cerrados. However, as yet, there was no regional scientific link to agriculture. Until this point, some technical improvements had made a mark in livestock farming, such as the emergence of national weight competitions, which allowed the selection of genetically superior breeds, and animal breeding centers that performed artificial insemination from the crossbreeding with European and Zebu breeds. South Goiás absorbed the results from the Unidade Experimental de Uberaba, which was created in 1930. In the 1950s, this research unit would be one of the pillars of bovine reproduction using frozen semen (ESPÍNDOLA, 2005). Rice, on the other hand, used the itinerant technique. As Waibel (1947) noted, there were no simple practices such as crop rotation and concerns about soil conservation.

Despite the significant advances of this period, the idea is that South Goiás evolved without leaving Quadrant 1. The market remained national. Productive links were scarce, urban centers were still being formed, and the urban network was poorly linked. Leading activities did not depend on research and skilled labor.

\section{Phase 3: Entering Quadrant 3}

Soybean cultivation brought new dynamics to the region, and while some effects of this change could already be observed in the 1970s and 1980s, they would become more evident in the 1990s and 2000s. Soybean was responsible for replacing the domestic agriculture with an activity linked to the international circuits (MACEDO, 2013).

This phase marked a greater link between industry and agriculture. In 2006, there was a total of 24,894 tractors in the South Goiás mesoregion. Of the total number of agricultural establishments, 9,253 used mechanical traction, which represented $21.3 \%$ of all properties and $39.0 \%$ of the area (IBGE, 2018b).

Nevertheless, the effects of upstream linkages remained limited. It is estimated that the participation of the pesticides sector in the VIT of Goiás was around $0.4 \%$. The manufacture of tractors and machinery and equipment for agriculture and livestock represented $1.7 \%$ of the VIT in Goiás in 
2007 (IBGE, 2019b).

With this, reliance remained on downstream industrialization. In 2007, the food sector accounted for $45.5 \%$ of the VIT in Goiás. The vegetable and animal oils and fats manufacturing sector, in which soybean processing was situated, represented $10.1 \%$ of the VIT in Goiás. Processing units had already been installed at the multinational companies Cargill in Rio Verde, and Louis Dreyfus in Jataí. Another important aspect was slaughtering and meat processing, which registered $12.1 \%$ of the state's VIT in 2007. Much was due to the installation of the Perdigão factory in Rio Verde in 1997. With these investments, the food sector in Goiás expanded to the rest of the country, accounting for $6.4 \%$ of the national VIT (IBGE, 2019a).

In 2000, the population of the South Goiás mesoregion was 1 million, of which $83.3 \%$ was urban. There was a displacement from the main urban center to Rio Verde, which now had a population of 116 thousand, followed by Itumbiara, with 81 thousand. In 2000, of the municipalities in the mesoregion, 54 had a total population of less than 10,000; 12 municipalities had a population of between 10 and 20 thousand; 9 municipalities had a population between 20 and 40 thousand; and five had a population of over 40,000 (IBGE, 2018c). Despite this significant increase, the population growth in South Goiás was low compared to the national and Goiás average. Between 1970 and 2010, the Brazilian population increased by $82 \%$; the population in Goiás grew by $70 \%$; and in the South Goiás mesoregion, it grew by only $48 \%$.

The transport axes were situated in order to meet the needs of exports. In 1999, the National Axes of Integration and Development (ENID) program was launched, thereby creating "agribusiness trade corridors" (DELGADO, 2012, p. 94). Goiás benefited from two major highways that linked the Port of Santos: the BR-050 and Anhanguera Highways and the BR-153 and Washington Luiz highways. Also of note was the rail axis, now under the control of the Ferrovia Centro-Atlântica (FCA).

During this period, some pioneering investments were made in universities in South Goiás. Most outstanding were the Fundação do Ensino Superior de Rio Verde (FESURV), created in 1973, and the Faculdade de Educação, Ciências e Letras de Quirinópolis (FECLEQ), created in 1988. In the case of research centers, we highlight the Monsoy unit, linked to Monsanto, located in Morrinhos, the Agency of Technical Assistance, Rural Extension and Agriculture and Livestock Research (Emater), in Goiânia, besides the work of Embrapa, in Brasilia. The scientific and technological infrastructure was thus, improved. However, the ties between soybean and local research were eventually reduced. On the one hand, this may be explained by the maturity with which research has enabled crops adapted to large areas and transgenic soybeans, with Roundup Ready (RR) technology, which inserts a genetic modification capable of creating resistance to glyphosate herbicide, of help in weed control. On the other hand, by the diffusion of the practice of adopting technology packages .

Given the weight of the international market for soybean, which connects Goiás to the global circuits, the forces of disintegration increase. These forces intensify in that the extent to which upstream threads are weak, the transport system acts as an export axis, and increased production may be undertaken with fewer links to the regional research system. In this context, the region moves to Quadrant 3.

\section{Phase 4: The Beginning Of Quadrant 4}

The activities that constitute the fourth phase are, in essence, the main products of the export list in South Goiás. Figure 4 demonstrates the predominance of soybean products (soybean, bran and oil) at the value generated from exports. The activities of animal products, which represents the sum of meat and milk products; sugar and ethanol production; and maize production grew from the second half of the 2000s. 


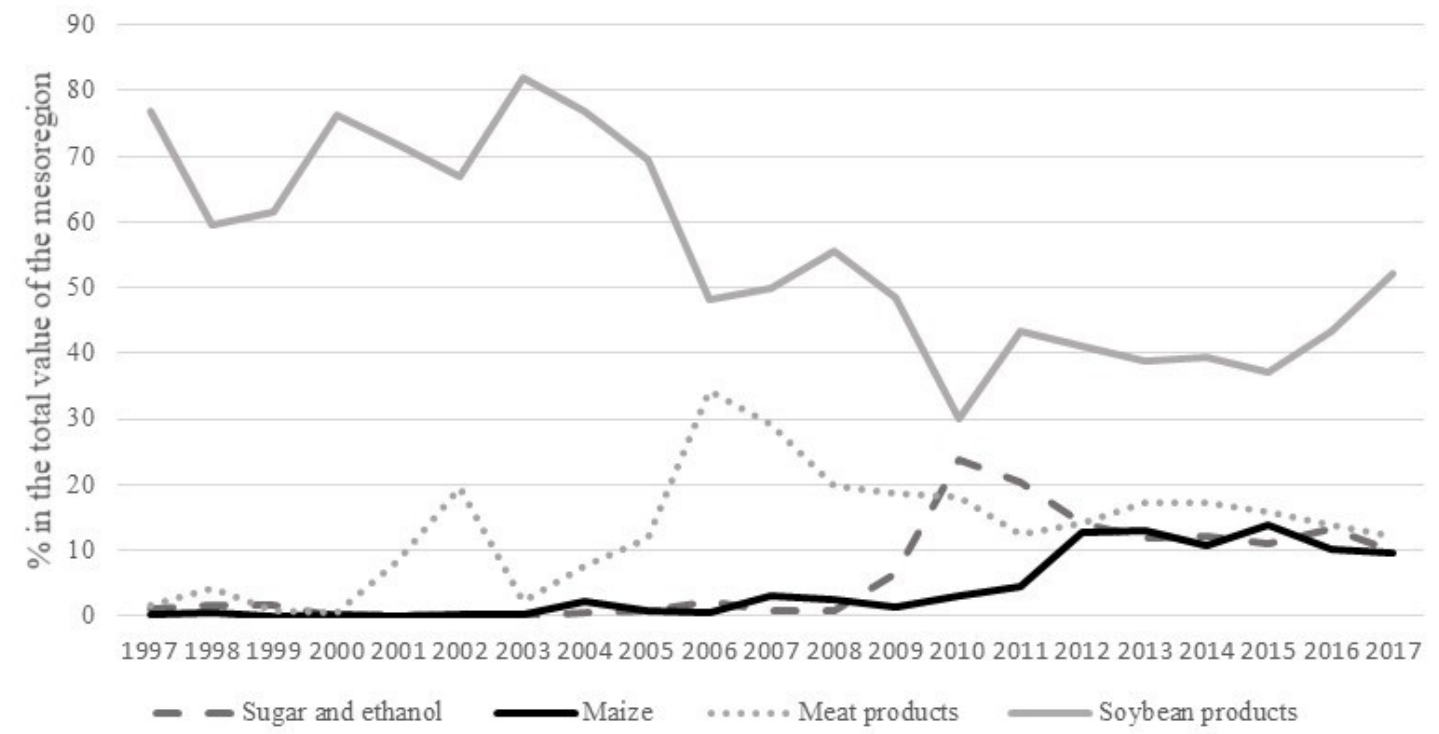

Figure 4 - The South Goiás Mesoregion: participation of soybean, meat. Sugar and maize products in the total exports of the region (in \% of the value). Source: Produced by the authors, 2018. Database MDIC

(2019a)

In 2017, the use of agricultural machinery intensified in the South Goiás mesoregion. That year, the region registered 16,153 tractors; 6,618 sowing machines; 3,409 harvesters and 6,183 fertilizers or lime spreaders (IBGE, 2018b).

The effects of upstream linkages began to appear, although still with certain limits. The chemical pesticide industry remained underrepresented, with 888 people employed and $0.05 \%$ of the VIT in Goiás in 2016. The tractor and farm machinery industry started to employ 786 workers and in 2016, represented $1.5 \%$ of the VIT of industry in Goiás (IBGE, 2019b). In this case, much is due to the John Deere plant in Catalão, installed in 1999. In 2012, this plant underwent its first expansion, and began production of sprayers. In 2014, a new investment was made to expand the production capacity and meet the demand for sugarcane harvesters and sprayers (FERREIRA, 2014).

In downstream industrialization, the food sector is most outstanding, which in 2016 registered $49.8 \%$ of the VIT in Goiás and $6.7 \%$ of the sector's VIT across the country. Food production underwent diversification (IBGE, 2019b). First, Perdigão (now BRF), in addition to the Rio Verde unit, expanded its slaughterhouse complex in Mineiros, Jataí and Buriti Alegre; animal feed factories and a group of integrated rural producers. Second, there was an advancement of the sugar-energy sector. As Castillo (2015, p. 98) explains, after harvesting, sugarcane "begins to degrade and must immediately be processed in the industrial units". Unlike soybean, which may be grown in one location and transported over long distances, the cultivation area of sugarcane must be close to the industrial unit

Furthermore, in Goiás there was an agroindustrial restructuring in the vegetable oils and fats sector, which lost relevance because of other productive branches. While, in 2016, this activity represented $10.6 \%$ of the VIT in Goiás, the slaughtering and meat manufacturing sector registered $14.4 \%$, and the sugar and biofuels sector became the main agroindustrial activity in Goiás, with $20.2 \%$ of the VIT. This change is illustrated in Figure 5. 


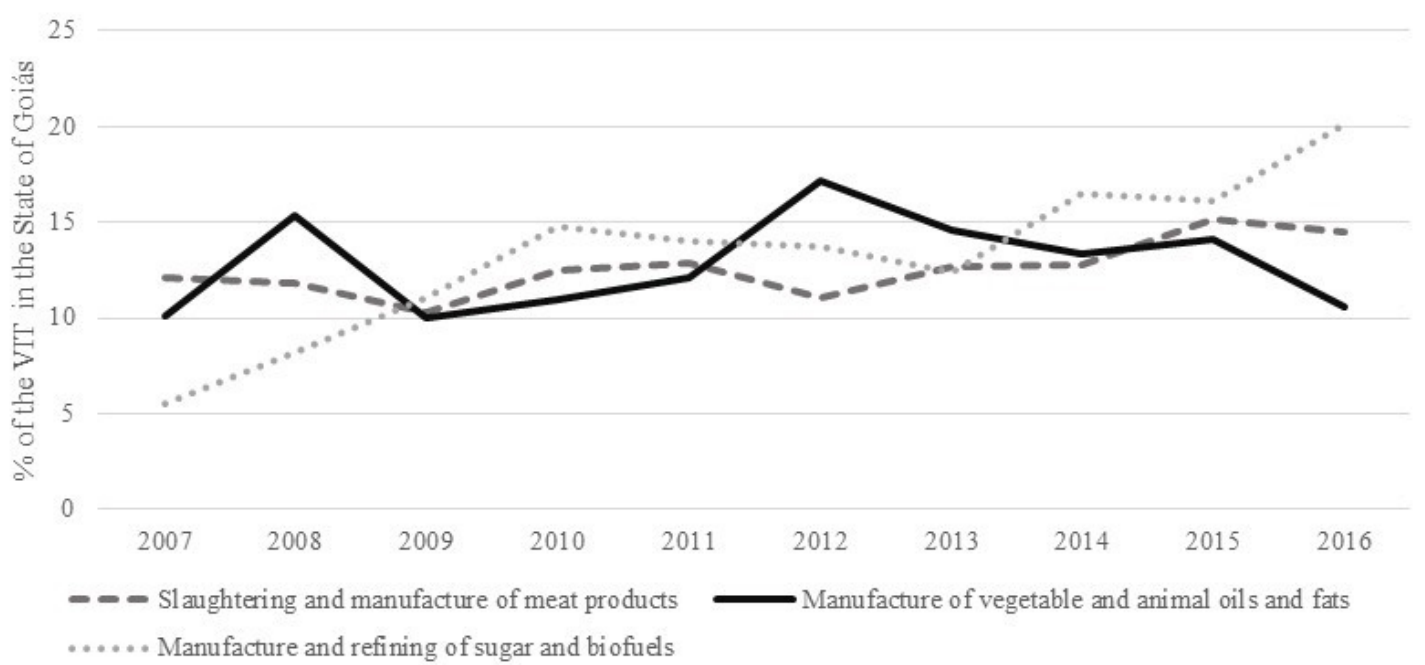

Figure 5 - The State of Goiás: the participation of the meat, vegetable oil and sugar-energy sectors in the state's manufacturing industry (in \% of VIT). Source: Produced by the authors, 2018. Database (IBGE, 2019b)

In 2017, the population of South Goiás was 1.4 million. There were five cities with a population of more than 80 thousand: Rio Verde (which reached a total population of 217 thousand), Itumbiara, Catalão, Jataí and Caldas Novas; 12 municipalities had a population of between 20 and 80 thousand; 12 municipalities of between 10 and 20 thousand; and 53 with a population of less than 10,000. Although the number of municipalities with a population of less than 10,000 inhabitants remained constant compared to phase 3, the total number of municipalities with a population of more than 20,000 has increased significantly. South Goiás has also grown above the national average and along with state. Between 2000 and 2017, while the Brazilian population increased by $22 \%$ and the population of Goiás grew 35\%, that of the South Goiás mesoregion increased by 36\% (IBGE, 2018d).

The growth of cities in the region has been accompanied by greater links within the urban network. At this point, it is important to highlight the role of the sugar-energy sector. Unlike soybean and meat agro-industries, located mainly in the largest urban centers (Rio Verde, Jataí and Itumbiara), sugar-energy units have moved to smaller cities, thereby increasing the productive capacity of these locations. Increased production has influenced the density of the urban network insofar as it intensifies the urban-rural relationship. The highways have expanded to allow access of the productive units to the cultivation zones. The arrival of these ventures in South Goiás has led the state government to invest in road transport in locations where the transportation system was deficient, thereby improving interregional integration. At the same time, the duplication of central highways, such as the Itumbiara-Goiânia axis, strengthens the region's integration into a national and international division of labor.

Figure 6 combines the location of the downstream industry in the region, featuring sugar cane mills, soy and meat processors (in this case, the BRF complex); the size of urban centers, demonstrating the growth of traditional centers and the emergence of new centers; and the organization of the transportation system. This information illustrates the evolution of the regional arrangement that makes up South Goiás. 

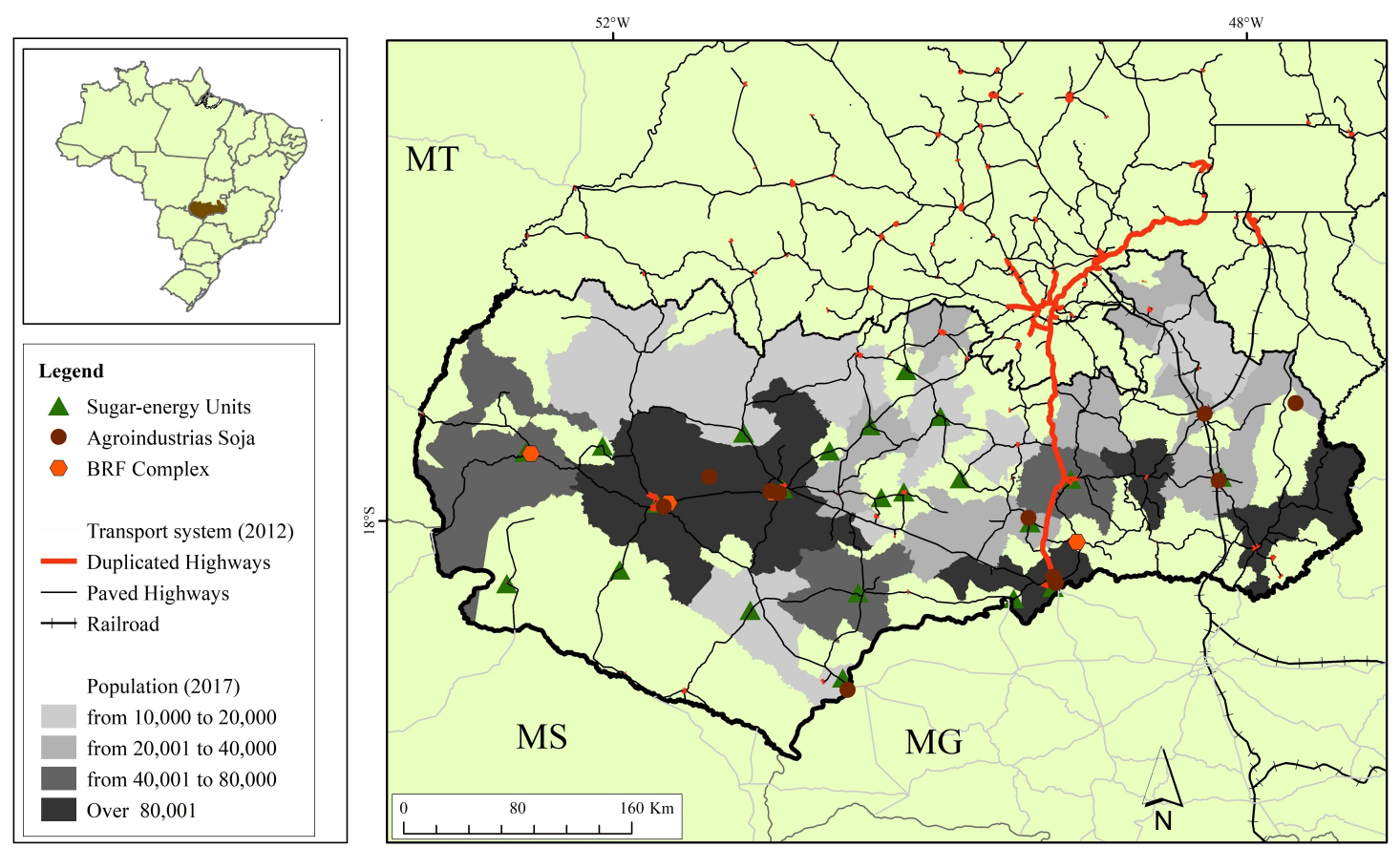

Figure 6 - The South Goiás mesoregion in phase 4: population (2017), transport (2012) and agro-industries (2017). Source: Produced by the authors, 2018. Database (IBGE, 2018c; BRASIL, 2019b)

Sugarcane has a greater dependence on knowledge infrastructure. The profitability of sugarcane depends on the ability of the producer to adapt the cultivation technique to the particularities of the region's climate and soil. On the one hand, the sector depends on genetic improvement to create varieties adapted to the conditions of the Cerrado. The use of varieties bred for São Paulo, relatively common across the region, limits productivity. In this field, in Goiás, we highlight the role of the Interuniversity Network for the Development of the Sugar-Energy Sector (Ridesa), which, since 2004, has a research unit at the Universidade Federal de Goiás (UFG). On the other hand, the sector depends on qualified manpower, suitable for the handling systems, and for the work in the sugar-energy units. This has created a university-company interaction for training professionals locally (MESQUITA; FURTADO, 2016). South Goiás has six campuses of the Universidade Estadual de Goiás (UEG) located in Edéia, Itumbiara, Santa Helena de Goiás, Morrinhos, Quirinópolis and Mineiros. Jataí has both UEG and UFG campuses; Catalão has a UFG campus. The Mineiros and Edeia units of UEG offer a technologist course in sugar and alcohol production; UEG, Itumbiara, and UFG, in Jataí, offer agronomy courses.

\section{CONCLUSIONS}

The transformation that has taken place in Brazilian agriculture from the early nineteenth century until the present time has involved a complex combination of structural and spatial changes. These transformations have occurred on a national and regional scale. The focus of this work was directed towards the transformations that occurred on a regional scale. At this level, while new technologies have been incorporated into the production system and the links with the industrial segment have been expanded, the arrangement of the producing regions has undergone changes, providing transport systems adapted to the flow of production, of urban networks, with the potential of providing services and labor, and a more consistent science and technology infrastructure. The trajectory of South Goiás illustrates a particular case of how the evolution in the regional arrangements has occurred in order to allow the growth of a scientific agriculture and thereby render its competitiveness viable.

South Goiás has been guided by productive diversification, which, although associated with different branches of agribusiness, has produced distinct spatial logics that have linked forces of both 
integration and disintegration. The argument that the 2000s (phase 4) has led to a transition towards a more complex regional arrangement with greater intra-regional integration is due to some key characteristics of the sugar-energy sector: a logic has been created whereby the destination market has become essentially national, which has allowed for greater internal control over the demand for manufactured products such as ethanol; the intrinsic characteristics of the sector, which, due to the requirement of proximity between the cultivation and processing zones, has extended the local value added; and the greater complexity in the agricultural management of sugarcane, which increases the need for research and skilled labor within the region. Soybean, on the other hand, is linked to an international market with little margin for value added. In addition, the possibility of being processed in distant regions reduces the links that could be created locally. However, despite favoring a more complex arrangement, the sugar-energy sector still has limits concerning regional dynamism. The main limiting factor is the low local linkage with the upstream sectors, which could lead to sophistication processes in the industrial park.

Economic dynamism, combining meat, soybean and sugarcane production, was the result of a favorable domestic and external scenario, although recently it has suffered depletion. The volume of ethanol produced, which grew more than 10-fold between 2000 and 2015, has been stagnant ever since. Meat production, with BRF, showed signs of crisis in 2018, which led to the deactivation of the plant in Mineiros. Quadrant 4 depends on maintaining the dynamism of these sectors, which are responsible for diversifying the region's economy. Under current circumstances, a continuous trajectory of complexification within the regional arrangement is no guarantee for the development of the region. The possibility of a retrogression to Quadrant 3 must also be placed on the agenda.

\section{ACKNOWLEDGEMENT}

AGRADECIMENTOS: O autor agradeço ao Programa Nacional de Pós-Doutorado (PNPD) da Coordenação de Aperfeiçoamento de Pessoal de Nível Superior (Capes) pela Bolsa de pós-doutorado que financiou esta pesquisa.

\section{REFERENCES}

BONACELLI, M. B. M.; FUCK, M. P.; CASTRO, A. C. O sistema de inovação agrícola: instituições, competências e desafios no contexto brasileiro. In: BUAINAIN, A. M.; BONACELLI, M. B. M.; MENDES, C. I. C. (Org.). Propriedade intelectual e inovações na agricultura. Brasília e Rio de Janeiro: CNPq, FAPERJ, INCT/PPED, IdeiaD, 2015. P. 89-110.

BRASIL. MDIC. Estatísticas de comércio exterior. 2019a. Disponível Acesso em: Jan. 2019.

BRASIL. DNIT. 2019b. Disponível em: . Acesso em: 25 jan. 2019.

CAMPOLINA, B. O Grande Cerrado do Brasil Central: geopolítica e economia. 2006. 231 f. Tese (Doutorado em Geografia Humana) - FFLCH, USP, São Paulo, 2006.

CANO, W. Raízes da concentração industrial em São Paulo. Campinas: Fecamp, 2007a. 310p.

CANO, W. Desequilíbrios regionais e concentração industrial no Brasil, 1930-1970. São Paulo: Editora da UNESP, 2007b. 382p.

CASTILLO, R. Dinâmicas recentes do setor sucroenergético no Brasil: Competitividade regional e expansão para o bioma Cerrado. GEOgraphia, v. 17, n. 35, p. 95-119, 2015.

CHAUL, F. Catalão e a república do trem de ferro. Revista UFG. n. 11, 2011.

DELGADO, G. C. Do capital financeiro na agricultura à economia do agronegócio: mudanças cíclicas em meio século (1965-2012). Porto Alegre: UFRGS Editora, 2012. 142p.

DINIZ, C. C.; VIERIA, D. J. Ensino Superior e Desigualdades Regionais: notas sobre a experiência recente do Brasil. Revista Paranaense de Desenvolvimento, v.36, n.129, p.99-115, 2015.

ELIAS, D. Agronegócio e novas regionalizações no Brasil. Revista Brasileira de Estudos Urbanos e 
Regionais, v. 13, n. 2, p. 153-167, 2011.

ESPÍNDOLA, C. J. As reformas dos anos 90 e a dependência tecnológica nas agroindústrias de carne no Brasil: o caso da genética anima. In: EGAL. 10, 2005. São Paulo. Anais... 2005.

ESTEVAM, L. A. O tempo da transformação: estrutura e dinâmica na formação econômica de Goiás. 1997. 203 f. Tese (Doutorado em Economia), IE, UNICAMP, Campinas, 1997.

FERREIRA, C. John Deere vai investir US\$ 40 milhões para expansão de fábrica em GO. Valor Econômico, São Paulo, 9 abr. 2014. Agronegócios. Disponível em: . Acesso em 15. Mar. 2018.

FIGUEIRA, S.; BELIK, W.; VICENTE, A. K. Escala e concentração das usinas de açúcar e álcool e empresas do setor no Estado de São Paulo. Congresso da SOBER. Anais...Goiânia: 2014.

FREDERICO, S. Modernização da agricultura e uso do território: a dialética entre o novo e o velho, o interno e o externo, o mercado e o Estado em áreas de Cerrado. Geousp, n. 34, p. 46-61, 2013.

FURTADO, C. Análise do modelo brasileiro. Rio de Janeiro: Civilização Brasileira, 1972. 122p.

HAESBAERT, R. Os dilemas da globalização - fragmentação. In: HAESBAERT, R. (Org.)

Globalização e fragmentação no mundo contemporâneo. Niterói: EdUFF, 2001. p. 11-54.

IBGE. Censo Industrial - Goiás 1970. Rio de Janeiro: IBGE, 1974.

IBGE. Produção Agrícola Municipal. 2018a. Disponível em: . Acesso em: 27 dez. 2016.

IBGE. Censo Agropecuário. 2018b. Disponível em: . Acesso em: 28 nov. 2018.

IBGE. Censo Demográfico. 2018c. Disponível em: . Acesso em: 19 set. 2018.

IBGE. Contagem da População. 2018d. Disponível em: . Acesso em: 21 dez. 2018.

IBGE. Pesquisa Industrial Anual (PIA). 2019a. Disponível em: . Acesso em: 30 nov. 2018.

IBGE. Pesquisa Industrial Anual (PIA). Tabulações Especiais. 2019b.

MACEDO, F. C. Transformação econômica, inserção externa e dinâmica territorial no Centro-Oeste Brasileiro: o caso de Rio Verde. Sociedade \& Natureza, v. 25, n. 1, p. 35-50, 2013.

MAMIGONIAN, Armen. Estudos de Geografia e de Pensamento Geográfico. 2004. 264 f. Tese (Livre-Docência) - Faculdade de Filosofia Letras e Ciências Humanas, Universidade de São Paulo, São Paulo, 2004.

MENDEZ, R. Geografía económica: la lógica espacial del capitalismo global. Barcelona: Eurosia Carrascal, 1997.

MESQUITA, F. C. Evolução do aprendizado na expansão da cana-de-açúcar para Goiás: o papel dos centros de pesquisa. Campo e Território: Revista de Geografia Agrária, v. 22, 2016.

MESQUITA, F. C.; FURTADO, A. T. Expansão da agroindústria canavieira e qualificação da mão-de-obra em Goiás (2006-2013). Sociedade \& Natureza, v. 28, n. 1, p. 67-82, 2016.

MULLER, G. Agricultura e industrialização do campo no Brasil. Revista de Economia Política, n. 6, p. 47-77, 1982.

NAVARRO, Z.; BUAINAIN, A. M. The global driving of Brazilian agrarian development in the new century. In: BUAINAIN, A. M.; SOUSA, M. R. DE; NAVARRO, Z. (Org.). Globalization and agriculture: redefining unequal development. Lanham, Boulder, New York, London: Lexington Books, 2018. p. 9-30.

NORTH, D. C. Location Theory and Regional Economic Growth. Journal of Political Economy, v. 63, n. 3, p. 243-258, 1955.

PAGE, B. Across the Great Divide: Agricultural and Industrial Geography. Economic Geography, v. 72, n. 4, p. 376-397, 1996.

PAGE, B.; WALKER, R. From Settlement to fordism: The Agro-industrial revolution in the American Midwest. Economic Geography, v. 67, n. 4, p. 281-315, 1991. 
PALACIN, L. O século do ouro em Goiás, 1722-1822. Goiânia: Editora da UCG, 1994. 174p.

SANTINI, G. A.; PAULILLO, L. F. Estratégias tecnológicas e aspectos concorrenciais das empresas de semente de milho híbrido e soja no Brasil. Informações Econômicas, v. 32, n. 10, p. 20-30, 2002.

SANCHEZ-HERNANDEZ, J. L. La región y el enfoque regional en Geografía Económica. Boletim de la A.G.E, n. 32, p.95-111, 2001.

SANTOS, M. Por Uma Outra Globalização. Rio de Janeiro: Record, 2010. 174p.

STORPER, M. The Regional World: Territorial Development in a Global Economy. Nova Iorque e Londres: Guilford Press, 1997. 338p.

VALVERDE, O. Geografia da pecuária no Brasil. In: VALVERDE, O (Org.). Estudos de geografia agrária brasileira. Petrópolis: Vozes, 1985. p. 244-261.

1 Referências à agricultura neste artigo se voltam tanto para a produção vegetal quanto animal.

2 Nesse sentido, a competitividade não é pensada apenas como um atributo das empresas, mas, como coloca Castillo (2015), como uma qualidade de algumas regiões.

3 A ideia de arranjos regionais refere-se a um conjunto de relações sociais e econômicas que se articulam no nível regional. Essas relações envolvem agentes (como as empresas, consumidores, trabalhadores e organizações); fatores (como recursos naturais, instituições e dotação tecnológica); e processos econômicos (produção, circulação e consumo) (SANCHEZ-HERNANDEZ, 2001, p. 96).

4 Essa escolha se deve à base de dados utilizada, que disponibiliza os dados apenas para o nível das Unidades Federativas.

5 Para o setor de alimentos, foi feita também uma análise a três dígitos.

6 Outra possibilidade seria uma agricultura cuja técnica está baseada em elementos tradicionais da região. Mas, como será discutido no próximo item, esse caso, associado ao quadrante 2 , será pouco relevante na trajetória econômica do Sul de Goiás. Portanto, o mesmo não foi incluído no método.

7 Funes (1986, p. 44) estima que, na época, o tempo gasto por uma tropa para se deslocar de Goiás para o Rio de Janeiro era de cerca de oito meses (FUNES, 1986, p. 44).

$8 \mathrm{O}$ dado aparece como sigiloso nas Tabulações Especiais. Foi feito um cálculo em relação à indústria química (dois dígitos) subtraindo o valor das outras atividades a três dígitos cujos dados estão disponíveis.

9 A Monsanto, por exemplo, tem um tipo de prestação de serviço de "assistência técnica pré e pós-venda. A empresa não só recomenda e orienta os agricultores no momento anterior à venda, como também acompanha o produtor durante todo o plantio" (SANTINI; PAULILLO, 2002, p. 26).

10 O dado do VTI do setor de biocombustíveis de 2014 apareceu como sigiloso. Como opção para não retirar esse ano da série de dados, optou-se por calcular o valor de 2014 com base na média de 2013, 2015 e 2016. 